meet the needs of both heavy and light industries, in addition to the general electrical requirements of the Australian public. This is of interest to manufacturers who supply electrical products to the Commonwealth. The number of factories has increased during the last ten years from 231 to 360 . It is of interest from the point of view of increased competition with overseas suppliers, apart from protective tariff duties, that the ratio per cent of salaries and wages to values of production has gone down from 68 per cent in $1930-31$ to 55.6 per cent in 1938-39. Similarly, the value of output per person engaged increased during the same time from $£ A .529$ to $£$ A.652. The range of electrical equipment now produced in Australia, although far from being sufficient to meet domestic requirements, covers a fairly wide field; and there is quite an extensive range of radio-equipment for ocean-going vessels, aircraft beacons of the new ultra-high-frequency type and short-wave receiving sets, all of which are being manufactured in the Commonwealth.

Despite E.xstralia's substantial production of electrical machinery and equipment, the annual value of which is now more than $£ A .7,000,000$, the value of total imports from overseas countries amounted in 1938-39 to approximately £A.5,700,000. Of the products imported, a considerable proportion is made up of items which as yet cannot be economically produced in the Commonwealth and are required to meet the steady expansion of secondary industries and public utilities. With the majority of European suppliers, with the exception of the United Kingdom, now unable to effect shipments, and with the German occupation of Holland, Denmark, Belgium and France, it will be necessary for consumers to seek other sources of supply, particularly for urgent electrical requirements. Although certain electrical commodities may at present be prohibited entry to Australia from non-sterling countries, this situation is subject to alteration from time to time. In the event of such products being unavailable from the United Kingdom or within Australia, licences to import from British North America would no doubt be obtainable.

\section{Lighting Installation of the Savoy Chapel, London}

THE King's Chapel of the Savoy, Strand, London, which is all that remains of the Palace and Hospital of the Savoy, is the personal property of the King by right of his Duchy of Lancaster, of which the Savoy became the centre in 1351. His Majesty, at the time of the Coronation, placed the Chapel at the disposal of the Royal Victorian Order, to be regarded as the Chapel of the Order. Recent additions made have launched it on a new era of importance, and it can now be used for the first time for ceremonial purposes. The Chapel stands low and was approached by a narrow flight of steps. Its new approach consists of a stone parapet with broad sideways flights of steps which make robed processions possible. A robing room and a new cloister are other additions to the ancient building. In the Chapel itself space-saving ideas have been carried out to make more room.
The Royal stalls have been designed as part of the new wall panelling where the old organ stood. A miniature electric organ, similar to the one in Canterbury Cathedral, has been installed. The beautiful ceiling of eighty-eight wooden panels has been cleaned and retouched to a parchment shade, and can now be seen to full advantage owing to the concealed lighting from the sills of the windows, which lights the whole of the interior of the Chapel, and in peacetime allows the stained glass to be seen from outside by transmitted light. The whole of the design of the lighting installation was carried out by G.V.D. Illuminators, Ltd.

\section{Hydraulic Structures Research in Canada}

THE National Research Council of Canada has recently provided in Ottawa facilities for hydraulic structures research. The new laboratory, which is a part of the Division of Mechanical Engineering, has been planned to supplement the limited facilities which are at present available in Canada for work of this kind. The design of structures such as canal locks, dams, spillways, gates and power plant details can be investigated and work may be undertaken on river hydraulic problems of limited extent. Many pipe-flow problems are also within the scope of the laboratory. A feature of the laboratory is the large flow of water available which will be adequate for the largest models that can be accommodated. A complete description, with drawings, of the new hydraulic laboratory was published recently in the Engineering Journal. Reprints (N.R.C. No. 937) are available from the National Research Council, Ottawa.

\section{Mr. F. C. Bawden}

Mr. F. C. BAwDen has been appointed head of the Department of Plant Pathology at Rothamsted Experimental Station, in succession to Dr. J. Henderson Smith, who is shortly retiring, having held the post since 1932. Mr. Bawden was a scholar of Emmanuel College, Cambridge, and after taking a first class in the Natural Sciences Tripos and the diploma in Plant Pathology, he spent five years as research assistant at the Potato Virus Research Station, Cambridge, under Dr. R. N. Salaman. In 1936 he transferred to Rothamsted to take charge of the investigations on virus diseases of plants, in which he has been conspicuously successful. He was invited last summer to lecture in the United States on his investigations, but returned to Great Britain shortly after the outbreak of the War.

\section{Agricultural Research Council: New Members}

ThE Committee of Privy Council for the Organisation and Development of Agricultural Research has appointed, to fill vacancies caused by normal retirement, Sir Robert Blyth Greig, and, after consultation with the president of the Royal Society, Prof. W. W. C. Topley, Prof. E. J. Salisbury and Prof. T. J. Mackie, as members of the Agricultural Research Council. Sir William Cecil Dampier and Mr. John Smith have been reappointed for a further term. 